\title{
Effectiveness of multiple tray-aerators in reducing Iron (Fe) water wells in Gowa Regency, Indonesia
}

\author{
Ronny ${ }^{1}$ and Abdul Hafid Hasim ${ }^{2 *}$ \\ ${ }^{1}$ Department of Environmental Health, Politeknik Kesehatan Makassar, Indonesia \\ ${ }^{2}$ Departement of Civil and Planning, Universitas Negeri Makassar, Indonesia
}

(Received 19 May, 2017; accepted 26 April, 2018)

\begin{abstract}
The aim of this study was to see the effectiveness of aeration in decreased levels of iron (Fe) in water wells before and after the aeration process using multiple tray aerator methods. The use of multiple tray aeration is expected to reduce the levels of iron (Fe) in water wells. This research is an experiment with 30 samples of good water that had higher levels of iron (Fe), which do not qualify as water obtained by non-random sampling in Gowa Regency. To find out the effectiveness decreased levels of iron (Fe) before and after aeration performed with SPSS statistical testing. The results obtained show the rate of decline in levels of iron $(\mathrm{Fe})$ average about $2.21 \mathrm{mg} / \mathrm{L}$ with an average percentage of $68.01 \%$ decline. Value levels of iron (Fe) on average after aeration obtained at $1.12 \mathrm{mg} / \mathrm{L}$. Although it has seen a decline the effective look at the results showed significant before and after the aeration is done but not yet clean water requirements with value levels of iron ( $\mathrm{Fe}$ ) up to 1.00. In contrast to the results of another study that the results of decreased levels of iron $(\mathrm{Fe})$ obtained only around $0.20 \mathrm{mg} / \mathrm{L}$ or simply a decline of about $10 \%$. The difference in the results achieved by the research conducted in the laboratory with a reduction of circulating air in the rooms was not big. To achieve the levels of iron (Fe) to fit the requirements it is necessary to further processing after aeration. Aeration method with multiple tray aerator can reduce levels of iron $(\mathrm{Fe})$ in water wells significantly but the results are not yet qualified to clean water.
\end{abstract}

Key word: Multiple tray aerator, Water wells, Level of iron

\section{Introduction}

Improving the quality of the water mainly has a very close relationship with the presence of dissolved oxygen (DO). On the surface of the water contained concentrations of oxygen which are a primary requirement regarding the quality of water for human use and biota in the water. In the process, oxygen is physically, or transfer or absorption of oxygen serves to fill up the oxygen in the water used. The usual method in the call with aeration. Then aeration in water treatment used to obtain better water quality by using additional tools commonly known as the aeration (Robison, Rita, 1994).
The aim was to cover clean water by 2014 approximately $38.23 \%$ of the region eight districts or $24.45 \%$ for the entire Gowa Regency. The majority of the community that the city gained ground water from wells dug well construction is one of the most shared and widespread used to take ground water to small communities and individual homes as drinking water with a depth of 7-10 meters from the ground (Humas, 2014).

Iron or manganese into the water because of biological reactions to the reduction or anaerobic conditions (without oxygen). If water containing iron or manganese is left exposed to air or oxygen, the iron or manganese oxidation reaction will occur slowly

*Corresponding author's e-mail: doelhvd@yahoo.com 
forming a precipitate or colloidal clumps of iron oxide or manganese oxide which is not expected. The colloidal precipitate will stick or fall behind in the piping system, causing stains on your laundry, and can cause problems in the distribution pipeline system due to be supporting the growth of microorganisms such as crenothrix and clonothrix that can clog the piping and can cause the color and an unpleasant smell (Said, 2005).

The preliminary data on examination content $(\mathrm{Fe})$ in water wells located in the hamlet Bontoala Pallangga District of Gowa Regency obtained iron content $(\mathrm{Fe})$ of $3.5 \mathrm{mg} / \mathrm{L}$, if the terms of Permenkes number 416/Menkes/per/IX/1990 about terms and monitoring water quality to achieve the water quality required a maximum of $1.00 \mathrm{mg} /$ liter, the concentration of iron $(\mathrm{Fe})$ contained in water wells do not meet the requirements as clean water and improper used of society (Menteri Kesehatan Republik Indonesia, 1990).

They often found that many residents are forced to use water that is not of good quality. Of course, this can have negative impacts on public health both in the short term and in the long term. The quality is not good in the short term can result in vomiting, diarrhea, cholera, typhoid, or dysentery. This can occur in a state of poor environmental sanitation. When the ground water and surface water contaminated by feces, automatically germs spread into the source of water used for domestic purposes. In the long term, water is of poor quality can lead to bone disease, dental corrosion, anemia and kidney damage. This occurs partly because of the presence of heavy metals many of which are toxic (poison) and may deposit in the kidneys (Suryana, 2013).

Efforts to do is the construction of water facilities, both individually and in the form of assistance from the Government that aims to provide healthy water for the community. The use of ground water through wells is one of the most commonly used, but the water obtained from wells is still not meet the requirements of raw water which can be used for everyday needs. Processing is the most feasible way to be able to reduce the contents of the groundwater quality standards which exceed the limits of clean water.

\section{Materials and Methods}

The study was conducted October 2016 in Gowa
Regency South Sulawesi Province, Indonesia. A study is an experimental research for their treatment to an object (the treatment group) that is not controlled by the comparison group (control group), which aims to determine the reduced levels of iron in the water wells.

For experimental research with strict supervision, the number of water wells required 30 samples (Roscoe, John, 1975); (Santoso, Singgih., 2014). Examples of water wells scattered village Bontoala, District Palangga, Gowa regency, which has a Fe content exceeded the standard quality, the sampling technique used non-random sampling. Measurement of the Fe content of water samples was done for 15 times in the treatment group and the control group. Each group is contacted with an air aerator for 30 minutes.

An aerator in this study made by Tray-type aerator consists of a series of a cross-sectional structure is very straightforward and inexpensive and requires little space. Basic cross-section drilled with a diameter of 5-12 $\mathrm{mm}$ at a distance of 30 to penetrate the rows of a cross section with holes, from here sparks coming down with a speed of $0.02 \mathrm{~m} 3 / \mathrm{sec}$. Tiered tray aerator usually built up between 4-6 stacking tray with a height of 1.2 to 3 meters (Departemen Kesehatan Republik Indonesia, 1991).

Working procedures on the multiple tray aerator as follows: (1) submit a sample of 10 liters of water into the tank; (2) By using the pump, (3) after the water passes through every step and accommodated at the end of the tank, the water in the raising and flowed back, this process lasted for 30 minutes; (5) After 30 minutes prepared and then let sit for 10 minutes in the tank end; (5) Read the Fe content using Nessler tube to read the content of Fe contained

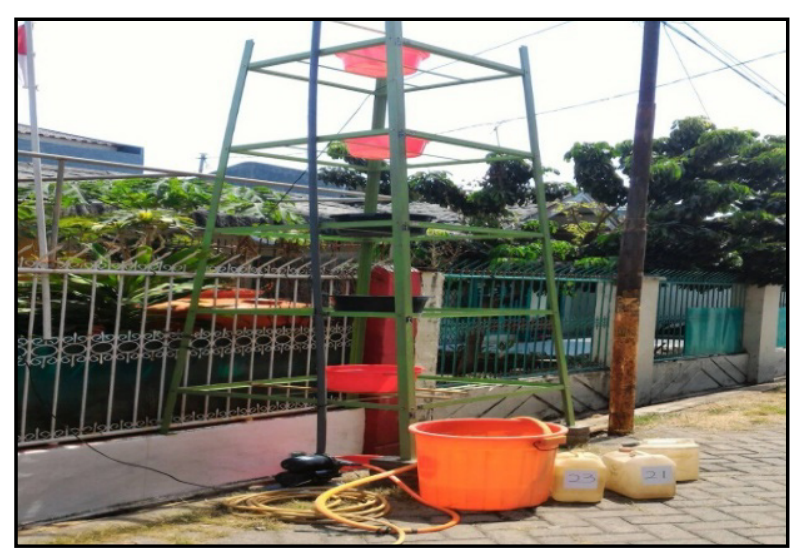

Fig. 1. Multiple Tray Aerators 
in water samples.

\section{Results and Discussion}

Figure 2 shows the results of studies using multiple tray aerator produces an average value level of iron (Fe) before the aerator obtained $3.51 \mathrm{mg} / \mathrm{L}$ and then once the process gained aerator $1.12 \mathrm{mg} / \mathrm{L}$. Costs decreased levels of iron ( $\mathrm{Fe})$ at least look at the sample number 15 whose grades fell to 2.27 with a percentage decrease of $66.18 \%$ and a maximum decline was seen in the sample number 4 with the value dropped to 2.49 with a rate decrease of $69.55 \%$. The average value decreased levels of iron (Fe) from 30 samples in this study were obtained 2.39 with the mean percentage decrease of $68.01 \%$.

Then to see the clear difference in the results before and after using aerator-type trays in the lower levels of iron $(\mathrm{Fe})$ in water wells then used statistical analysis paired sample t-test with SPSS Program. The results of the analysis will be shown in Table 1.

Table 1 shows the mean values obtained at 2.38733 , the value of standard deviation obtained at 0.05680 , at count value obtained at 233.137 and

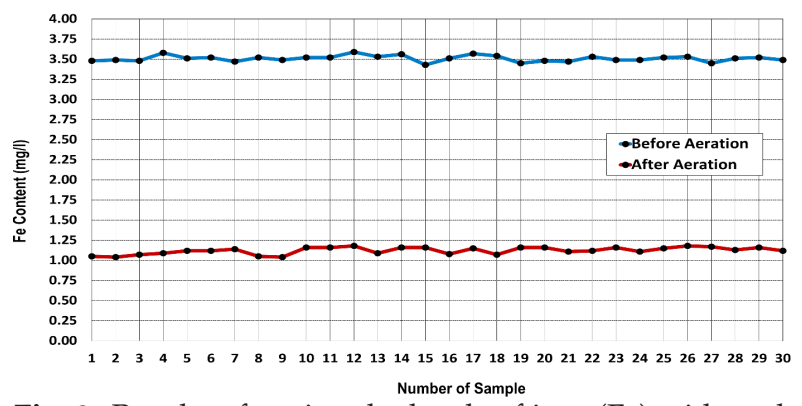

Fig. 2. Results of testing the levels of iron (Fe) with multiple tray aerator

probabilities value (sig. 2 tailed) was obtained for 0.000 .

Decision-making is based on the value of $\mathrm{t}$-count and t-table will always be equal to a conclusion from probability figure. There is a tendency probability figure more commonly used as a basis for making conclusions inferential (Santoso, Singgih, 2014).

Table 1. Difference test of the samples before and after the aeration

\begin{tabular}{lcccrr}
\hline & Mean & $\begin{array}{c}\text { Std. } \\
\text { Deviation }\end{array}$ & t & df & $\begin{array}{c}\text { Sig. } \\
\text { (2-tailed) }\end{array}$ \\
\hline Before-After & 2.38733 & .05680 & 233.13729 & .000 \\
\hline
\end{tabular}

The probability value (sig.) obtained by 0.000 or less than 0.05 by therefore can be established that there is a real difference level decreased levels of iron $(\mathrm{Fe})$ water wells before and after using a multiple tray aeration.

From the results obtained indicate the level of reduced levels of iron $(\mathrm{Fe})$ average about $2.21 \mathrm{mg} / \mathrm{L}$ with an average percentage of $68.01 \%$ decline. Value levels of iron $(\mathrm{Fe})$ on average after aeration obtained at $1.12 \mathrm{mg} / \mathrm{L}$. Although there has been a significant decrease before and after the aeration is done but not yet clean water requirements with value levels of iron (Fe) up to 1.00. To achieve the levels of iron $(\mathrm{Fe})$ to fit the requirements it is necessary to further processing after aeration. But the magnitude of decreased levels of iron (Fe) in this study can not be separated from the sites were made at the area reduction of circulating air at the time the research was blowing well then high aeration-type trays which make the gas diffusion transfer process occurs when water droplets that fall on a-hole trays holes for aeration. These conditions and coupled with the type of aeration used is the type of plates then seen the results obtained to be more efficient in reducing levels of iron $(\mathrm{Fe})$ in water wells. The oxidation of iron and manganese compounds in the water does not always happen at the right time. If the water contains organic substances, the formation of compounds of iron and manganese through aeration process will look very ineffective (Muntu, 2016).

The conditions for aeration indicates there has been a gas diffusion transfer process, which the distribution that occurs between air and water meet current water falling from the holes in multiple tray aerator. Turbulence will indirectly increase the rate of displacement of air/oxygen caused an accelerated rate between the contact surface, resulting in oxygen deficit will be maintained constant so that it will cause the value of the oxygen transfer coefficient is increased (Benefield, et al., 1981). In contrast to the results of another study that the results of decreased levels of iron (Fe) obtained only around 0.20 $\mathrm{mg} / \mathrm{L}$ or simply a decline of about $10 \%$. The difference in the results achieved by the research conducted in the laboratory with a reduction of circulating air in the rooms was not big (Kadir et al., 2015).

It is also observed that none of the predictive models predict the oxygentransfer efficiencies of all the treatment plants accurately. In this case, can be related to thefact that these empirical predictive equations have been developed for different hy- 
draulic structures using physical properties of the structure or the flow conditions to estimate the oxygen transfer efficiencies. Though in some cases the standard deviation is less than $10 \%$, these models should still be used with caution. This emphasizes the need for a new equation specifically for step pedaerators since existing models were not developed for stepped aerators, butfor weirs or other hydraulic structures (Koduri and Barkdoll, 2004)

The presence of surface active agents then organic substances, as well as dissolved solids in the water, causes the aeration process can be less than the maximum. Active substance on the surface, in particular, would appear to make corrections in the aeration process by reducing the surface tension and form a diffusion resistor at the interface between water and air and can also affect the hydrodynamic characteristics of the flow (Gameson, 1957); (Markofsky et al., 1978).

Experiments carried out in detail is done using the cascade aeration method showed that water could trap oxygen while descending the stair and an increase in oxygen levels in the water. Cascade aeration in this experiment can be used as an adequate aeration condition or area of interest is in the field of the river, canal, pond fish hatchery, water treatment plants, etc. (Ahmet Baylar, et al., 2006); (Emin Emiroglu and Baylar, 2006); (Ahmet Baylar et al., 2009).

\section{Conclusion}

Aeration method with multiple trays indicates effectively as seen from the results of research which significantly lowers the levels of iron $(\mathrm{Fe})$ water wells that were sampled sample. Although calculations and studies have shown that decreased levels of iron (Fe), but in the end the result of the average value of the levels of iron (Fe) which was obtained at 1.12 $\mathrm{mg} / \mathrm{L}$ is still beyond the maximum limit set is 1.00 $\mathrm{mg} / \mathrm{L}$ in accordance with the requirements of the Ministry of Health Republic of Indonesia on the conditions and water quality control. Results from this study are the first step to obtaining clean water for communities by implementing advanced water treatment after processing by using multiple tray aerator.

\section{References}

Baylar, Ahmet., Bagatur, Tamer and Emiroglu, Emin, 2007.
Aeration efficiency with nappe flow over stepped cascades. In: Proceedings of the Insitution of Civil Engineers. 43-50.

Benefield, Larry D. and Randall, Clifford W. 1981. Biological process design for wastewater treatment. In Prentice Hall Series in Environmental Sciences. Prentice hall.

Departemen Kesehatan Republik Indonesia, 1991. Pedoman Teknis Perbaikan Kualitas Air. Dit-Jen P2M Dan PLP Direktorat Penyediaan Air. Jakarta, 104.

Emiroglu, M. E., and Baylar, A. 2006. Self-aeration in smooth and stepped chutes. International Journal of Science and Technology. 1(2) : 105-113.

Gameson, A.L.H. 1957. Weirs and aeration of rivers. Journal of the Institution of Water Engineers. 11 (5) : 477490.

Humas Gowa. 2014. Peresmian IKK Bontomarannu PDAM Gowa Kabupaten Gowa. Retrieved March 22, 2017, from http:/ / humasgowa.com/index.php/ tag/peresmian-ikk-bontomarannu-pdam-gowa /

Kadir, Destriana., Kadir, Sunarto, and Amalia, L. 2015. Gambaran Kandungan Kadar Besi (Fe) Dan Mangan (Mn) Pada Air Sumur Gali Dengan Metode Tray Aerator (Studi Kasus Di Kelurahan Moodu Kota Gorontalo). Jurnal KIM Fakultas Ilmu-Ilmu Kesehatan Dan Keolahragaa. 3 : (3).

Koduri, S. and Barkdoll, B. D. 2004. Evaluation of Oxygen Transfer at Stepped Cascade Aerators. World Water Congress.

Markofsky, Mark. and Kobus, Helmut. 1978. Unified presentation of weir-aeration data. Journal of Hydraulics Division. 104(4) : 562-568.

Menteri Kesehatan Republik Indonesia. 1990. Peraturan Menteri Kesehatan Nomor/: 416 / MEN. KES. / PER/IX /1990. Tentang Syarat-syarat dan Pengawasan Kualitas Air.

Muntu, R. 2016. Penyehatan Air. Politeknik Kesehatan Makassar (Vol. 1). Makassar: Unit Penelitian Poltekkes Makassar.

Robison, Rita, 1994. Chicago's Waterfalls. American Society of Civil Engineers. 64 (7) : 36-39.

Roscoe, John T. 1975. Fundamental Research Statistics for the Behavioral Sciences (2nd ed.). New York: Holt, Rinehart and Winston.

Said, Nusa Idaman. 2005. Metoda penghilangan zat besi dan mangan di dalam penyediaan air minum domestik. Jurnal Air Indonesia. 1(3).

Santoso, Singgih. 2014. SPSS 22 from Essential to Expert Skills. PT. Elex Media Komputindo. Jakarta: PT. Elex Media Komputindo.

Suryana, R. 2013. Analisis Kualitas Air Sumur Dangkal di Kecamatan Biringkanayya Kota Makassar. Fakultas Teknik, Universitas Hasanuddin, Makassar. 